\title{
An Empirical Study of Capability Development within Product Innovation Projects
}

\author{
Alireza Javanmardi Kashan', Kavoos Mohannak ${ }^{2}$
}

\begin{abstract}
The objective of this paper is to develop insights into firms' strategic capability development processes within product innovation projects. In particular, the research aims at investigating the interactions among product innovation, knowledge processes, and capability development within firms. Building on qualitative data from the auto-industry, our analysis reveals that across four product innovation projects, the case company developed architectural knowledge and capability. Findings reveal that, along with changes at each level of product architecture, "design knowledge" and "design capability" have been developed at the same level of product architecture, leading to capability development at that level. Furthermore, findings suggest that such capability transformation resulting from knowledge and capability creation over the course of case projects leads to modularization of product architecture. Overall, the research contributes to identifying and emphasizing the role of micro processes in capability development and renewal, which in turn enhances our understanding of strategic capability development processes.
\end{abstract}

Keywords: capability development; auto-industry; knowledge integration; product innovation

\footnotetext{
1,2Queensland University of Technology, QUT Business School, School of Management, 2 George Street, Brisbane 400I Australia E-mail: ${ }^{2}$ k.mohannak@qut.edu.au (Corresponding Author)
} 


\section{Introduction}

The resource based view argues that competitive advantage and disadvantage of a firm is rooted in the heterogeneity of its capabilities and resources in a population of firms (Barney, 1991). Based on the dynamic resource based view (Helfat \& Peteraf, 2003), such competitive advantage and disadvantage comes about over a period of time, and also may shift over time. However, we are still not clear on how resources and capabilities that form the basis of competitive advantage evolve over time. Within the existing literature, although there is an increasing range of conceptual elaboration about capability renewal, empirical support is limited (Ambrosini \& Bowman, 2009).

Considering the fact that heterogeneity in resources and capability is the cornerstone of the resource based view (Hoopes, Madsen, \& Walker, 2003; Peteraf, 1993), the lack of a clear understanding within the resource based view of how this heterogeneity arises may account for such deficiency in the literature. Absent is an understanding of where heterogeneity in resources and capabilities comes from, making it difficult for researchers to fully explain how firms manage technological innovation to renew their resources and capabilities, and hence, create competitive advantage. This gap in our understanding also makes it more difficult to offer prescriptive advice to managers as well.

In order to shed light on this vagueness, an in-depth understanding of the dynamics of competitive advantage can be better gained by a focus on the role of organizational micro processes. The emerging micro perspective is increasingly playing an important role in terms of developing an understanding of both capability renewal (Johnson, Melin, \& Whittington, 2003) and how the firms' competitive positions are achieved over time (Pettigrew, 1990). Consequently, this study takes a micro perspective approach to learn about the mechanisms underlying the development of distinctive resources and capabilities.

In this regard, product innovation is empirically found and conceptually emphasized as a critical context for development of competitive capabilities (Danneels, 2002; Esenhardt \& Martin, 2000; Grant, 1996; Slater, Mohr, \& Sengupta, 2014). Operating at project level, therefore, product innovation is an important micro process underlying capability development. Accordingly, this study investigates the interplay between product innovation and capability development to shed more light on the nature of capability development within firms. For this purpose, this research has adopted a case-based approach and investigated the case of a successful firm that could sustain its competitive capability through capability development over the course of a series of product innovation projects. In particular, this research has focused on the processes of capability development over the course of four projects, during which this firm has successfully managed the transformation of its product base and renewal of its competitive advantage. The study is undertaken in the context of an emerging economy, which provides an appropriate context for researching the link between firm-level capacity development and projectlevel innovations. For this purpose, an in-depth case study of capability development was undertaken at Iran Khodro Company (IKCO) as the key player in the Iranian auto industry transformation.

\section{Theoretical background}

The resource-based view (Barny, 1991) argues that organizational resources which are valuable, rare, inimitable, and non-substitutable are sources of competitive advantage. It has been argued by Barney, Wright and Ketchen (200I) that the major sources of competitive advantage are not the distinctive resources themselves, but the organizational capability upon which the distinctive resources are made. Hence, when a firm's competitive advantage is eroded as a result of rivals" resource developments, the firm will have to develop organizational capabilities in order to develop their resources and competitive advantage.

However, literature on organizational capability development has approached organizational capability development by emphasizing either its content or process. Such a separation created two different views within the literature: a competence-based view (Sanchez \& Heen, 2004), which emphasizes the content of capability development, including the entrepreneurial aspect of organizational capability development based on examining the impacts of external opportunities on capability development; and a capabilitybased view (Dosi, Nelson, \& Winter, 2000), which addresses the process of capability development, focusing on the strategic aspects of organizational capability development by studying the impacts of past organizational capabilities (and path dependency) on capability development.

With the rise of micro perspective (Pettigrew, 1990), a new approach in strategic management is established which goes actually beyond the discussed opposing views of competence based and capability based. Contrary to the traditional resource based view, scholars of this field argue that instead of theorizing about the distinctiveness of resources we should study the gradual emergence of this distinctiveness over time (e.g., Eisenhardt and Santos, 2002). Sminia (2009) has referred to such a movement in research as replacing "how" questions with "how to" questions in strategy process research. He explained that, in research involving a resource based view, instead of studying the characteristics of distinctive resources and capabilities 
and their relationships with performance, research should theorize about how these characteristics are achieved over time. Based on this view, competitive capability is built using an underlying mechanism, which is the engine of continuous change processes and is called a "generative mechanism" by Pettigrew (1990). Generative mechanisms are argued to include reciprocity between the firms" path dependencies and market changes (Sminia, 2009).

Therefore, this view may link competence based and capability based views in conceptualizing capability development as the evolution of organizational past capabilities towards market requirements. Such definition of capability development is referred to as strategic capability development in this study. More specifically, Kashan and Mohannak (20I4; p. I) defined strategic capability development as "a renewal of an organization's existing capability in line with the capability required by the market in order to create or regain competitive advantage". Hence, it is expected that by enhancing the understanding of strategic capability development, knowledge can be gained about how competitive advantage (as distinctive from resources) is made. However, we have not yet a clear empirical understanding of such a strategic capability development process. Due to the before mentioned role of generative mechanism, shedding light on the nature of co-evolutionary relationship between micro processes and development of strategic capability could contribute to clarification of this process.

In this regard, one of the critical micro processes in the context of capability development is product innovation (Eisenhardt \& Martin, 2000). Ever since Schumpeter's (1942) classic work, the interrelationships between product innovation firms' maintaining or regaining competitive advantage have been a crucial area of theory development and academic debate. On one hand, some scholars have emphasized the role of product innovation in strategic renewal (Danneels, 2002; Eisenhardt \& Martin, 2000). On the other hand, there is a large number of firms who could not benefit from product innovation for protecting their competitive advantage, and some authors suggest that such failure in linking innovation to performance is due to lack of capability development in the process of product innovation (Slater et al., 20 I4;Verona \& Ravasi, 2003). Micro perspective view (taking product innovation as a micro process at project level) can integrate such findings on the impact of product innovation on capability development and vice versa by suggesting a reciprocity between product innovation and development of competitive capability. Aligned with this view, Danneels (2002) argued that product innovation coevolves with capability development and so is a means for capability transformation. One of the major micro processes underlying such co-evolutionary relationship between product innovation and capability development is known to be knowledge processes (Grant, 1996). Basically, there is a strong interrelationship between knowledge processes and capability development in firms which has both conceptually (Kashan \& Mohannak, 20I4; Lichtenthaler \& Lichtenthaler, 2009;Tippmann, Mangematin, \& Scott, 20I3; Zollo \& Winter, 2002) and empirically (Cavusgil, Calantone, \& Zhao, 2003; Lichtenth, 2009; Lichtenthaler \& Ernst, 2007; Liu, Chen, \& Tsai, 2004; Lupton.\& Beamish, 20l4; Subramaniam \& Venkatraman, 200I) emphasized. Despite such an emphasis on the role of product innovation in making up the generative mechanism and capability development, we are yet less clear about how product innovation co-evolves with capability development. This makes a justification for this research to investigate the interactions between product innovation projects and capability development at firms in order to get a better understanding about strategic capability development processes.

\section{Research method and design}

In accordance with the aim of this research, the study was designed with the purpose of developing insights about firm" strategic capability development processes based on investigating the interactions among product innovation, knowledge processes, and capability development within firms. Accordingly, the present research might best be described as theory elaboration (Lee, 1999; Lee, Mitchell, \& Sablynski, 1999) in that it elaborates theoretical links not previously addressed in the literature. For example, previous studies on capability development have emphasized either institutional environment influences or firms' specific processes, resulting in apparent contradictions described earlier. Thus, this research attempts to "simplify, reconnect and redirect theory" (Lee et al., 1999, p. 166) on capability development, in a way that interprets micro processes of capability development.

\section{Research setting}

The industrial dynamics studies conducted in the context of developing countries revealed that industry development within developing countries follows different patterns to those in developed countries. Kim (1980) noticed that, unlike developed countries" models of industrial development which follow product innovation to process innovation, within developing countries, industry development starts from process innovation and then proceeds to product innovation. In this regard, some authors like Lee (2005) have demonstrated that the process innovation period (as the beginning of industrial development) is a "technology catch-up" period. More specifically, Rush, Bessant and Hobday (2007) argued that during the process development (technology catch-up) period, firms in developing countries 
are actually learning the capability to be able to undertake product innovation. Therefore, while industrial development in developed countries is based on a firm's capabilities which are already developed, industrial development in emerging economies includes developing capabilities within firms.

The Iranian Government, as with other developing countries, has planned for economic liberalization during past decades. Accordingly, the Iranian Government has supported industrial development and encouraged firms in capability development. Special considerations have been given to the development of the auto industry due to its strategic value for the future prospects of the country. The Iranian automotive industry has been subject to several market changes over the last three decades due to government policy on import replacement in this sector. As Koohi (2006) explains, this industry started in Iran in 1966 and until 1989, government provided the industry with the minimum support. However, during 1989 to 1994 the government sensed the strategic value of the industry and started with extensive investment in this industry. Particularly, from 1994 to the present has been an awakening and learning period, which has received the full support of government. Government policy has been focused on developing the whole auto industry, especially through capability development at the Iran Khodro Company (IKCO) as the leading car maker in Iran. Hence, the government has protected IKCO"s market share (along with some other minor car makers) in order to provide the firm with a secure period of time for capability development. IKCO is the major car producer within the Iranian auto market having more than $60 \%$ of the market share. IKCO started in 1966 by assembling a sedan called "Peykan", based on an alliance with a British company. However, the company kept on producing Peykan in its original form until 1988 when the government decided to invest in this industry, and supported maturation of locally produced products and establishment of the industry at different associated layers within the industry value chain.

Consequently, in 1989, IKCO started its three-year strategic alliance with Peugeot and gradually started to restructure and establish specialized internal departments (e.g., research and development, engineering and production, strategic planning and studies, and marketing departments, etc.) as well as subsidiary companies including SAPCO (Supplying Automotive Parts Company, TAM (engineering \& construction company), ISACO (spare parts \& after sales services), IPCO (Iran Khodro Powertrain Company), etc. As a result, after 39 years, production of Peykan was phased out in 2005 , indicating a turning point in the company's history technology-wise, with a focus toward better customer satisfaction. In this regard, IKCO developed its first "national engine" and installed it in its products. Furthermore, it was able to develop leading edge knowledge for designing
CNG-based (Compressed Natural Gas) engines, targeting the global market. IKCO was also producing quality products (receiving an EFQM award in 2007) and diversified its products into different market segments to protect its local market share from international brands. Once having a single site for production, it now has six sites in different Iranian cities (Tabriz, Shiraz, Mashhad, Semnan, Tehran, and Babol) and also six other sites in different countries around the world (Syria, Belarus, Venezuela, Egypt, Senegal, and Azerbaijan). IKCO is now the leading car maker in the Middle East, Central Asia and North Africa, ranking 14th in the world and positioning the Iranian auto industry at 16 th in the world.

The use of extreme cases facilitates theory elaboration because the phenomenon under investigation is "closer to the surface" and easier to observe (Eisenhardt, 1989; Pettigrew, 1990). Therefore, as the knowledge and capability development at IKCO has resulted in the formation of the industry structure of the Iranian auto industry, IKCO presents as an excellent context for examining the research aim of this study.

Aligned with the theoretical background discussed earlier, this study proposes that such capability development is achieved through knowledge processes managed across product innovation projects. A review of the case company's product innovation projects within the pilot study showed that capability has matured in this firm over a period of 18 years and over the course of four product innovation projects. Table I shows the sequence of these projects and indicates the period of time that each project spanned within the 18 years of IKCO"s capability development. Characteristics of these projects (Pars, Samand, Soren, and Dena), as shown in Table I, match with archetype product innovation projects as suggested by Sanchez and Mahoney (1996). Accordingly, this study is designed to examine the knowledge processes undertaken and capability development process within the IKCO company across the sequence of these product innovations. 


\begin{tabular}{|c|c|}
\hline $\begin{array}{l}\text { Pars project (1994- } \\
\text { I997): } \\
\text { Incremental innova- } \\
\text { tion }\end{array}$ & $\begin{array}{l}\text { Samand project } \\
(\text { I996-200I): } \\
\text { Modular innovation }\end{array}$ \\
\hline $\begin{array}{l}\text { Soren project } \\
\text { (2005-2008): } \\
\text { Architectural inno- } \\
\text { vation }\end{array}$ & $\begin{array}{l}\text { Dena project (20I0- } \\
20 \mid 2) \text { : } \\
\text { Radical innovation }\end{array}$ \\
\hline
\end{tabular}

Table I

Pars project: From 1994 to 1997, car imports were restricted (based on tariff rates between $90 \%$ and 195\%) to save the market for IKCO, and therefore, imported cars were very expensive, and as the volume of local production was limited, long queues for product purchase resulted (people paid up to two years upfront for product purchase). This situation minimized the risk of developing a new car and IKCO decided to work with Peugeot to transfer its platform technology used in the Peugeot 405. Meanwhile, local suppliers were encouraged to localize part production to achieve self-sufficiency in producing the Peugeot 405. Finally, Peugeot Pars (in this paper referred as Pars), which was a semi-developed idea of Peugeot, was co-developed by IKCO.

Samand project: Before this project, since Peugeot was the brand owner, IKCO had limitations in making changes. Accordingly, IKCO took a big step toward capability development by developing a "national car" called the Samand. The design of this car, between 1996 and 200I, was managed by IKCO and learning was key priority-not profit making - and the company emphasized long-term returns. Developing the Samand, in brief, allowed IKCO to design a car which met most of the Iranian market's needs (as its major target market) and was adaptable based on market dynamics.

Soren project: Since the Samand was IKCO's first experience at designing a car under its brand, the failure rate reported by consumers was higher than normal. These reports indicated that IKCO had not yet completed the learning cycle and still needed to apply the knowledge which was learned during the Samand project. Accordingly, IKCO created an internal force to amend the Samand's design. The Soren was designed at IKCO between 2005 and 2008. In this project, some of the Samand's subsystems were replaced by new high-tech subsystems. Furthermore, local suppliers grew and made alliances directly with foreign partners. After establishing their production lines within the Pars and Samand projects, the local suppliers started to learn about designing subsystems, and gradually formed their own research and development (R\&D) departments (as distinct from IKCO's existing R\&D departments).

Dena project: Based on a general trend toward economic liberalization, the custom tariff for car imports started to decrease from 2009 and the rate of car imports dramatically increased. Since foreign car producers had developed cars for different price segments of the market, in the Iranian market they could offer products closer to consumers' requirements (in terms of quality and price) than IKCO could. To compete with such international competitors, IKCO had to aggressively develop a new car for a critical price segment of the market in which foreign products threatened IKCO's existing products. Accordingly, between 2010 and 20I2, IKCO developed the Dena as a luxury product based on up-to-date technology with a competitive price in the market. In this product, in addition to changing subsystems using up-to-date technology, a configuration of subsystems was selected in order to create the luxury attributes that consumers were looking for while still being affordable for a range of consumers to buy.

\section{Data collection}

This study used semi-structured interviews and secondary sources of information for data collection. In this regard, two rounds of interviews were conducted to collect rich data from different perspective on the phenomenon of research. Thirty-seven key informants with more than 10 years of experience were selected from the case projects to give information on different product innovation projects and capability development processes within each case project. In the second round of interviews, 10 interviews were made at organizational level with senior managers of IKCO and SAPCO companies. The interviewees were selected based on information gained through the pilot study. The interviews were conducted during 22 site visits and within a four-week time frame. The training department of IKCO as the official channel for administrative arrangements developed a mutually convenient schedule of interviews for researcher and interviewees. The interviews were mostly conducted at interviewees' workplaces and data collected at the project level.

These interviews with organizational members involved in new product development were conducted to assess their perspectives on and experiences with knowledge integration within product innovation. Each participant was asked questions about a specific product innovation project. Some of the reports by interviewees were retrospective (Miller, Cardinal, \& Glick, 1997), other reports were contemporary with the activities they described. Interviewees were drawn from various organizational levels. Data about development processes and projects were compared and integrated 
across informants. During all interviews, informants were encouraged to illustrate their statements with specific events and examples from specific projects.

In addition, secondary sources of information were used, including company websites, annual reports, newsletters and news websites, other related websites, and company archives. These sources of information were used for collecting data about the development of existing capabilities in IKCO across four product innovation projects: Pars, Samand, Soren, and Dena.

\section{Findings}

Data collected in the case company and across case projects revealed a pattern of maturation of product innovation projects toward radical innovation, along with development of architectural knowledge and capability within the IKCO company. Findings also showed that, in accordance with such knowledge and capability development processes across the product innovation projects, a modular product architecture has emerged at the case company.

\section{Maturation of radical innovation across the case projects}

A comparison between the depth of changes (depth of innovativeness) in IKCO's products developed within the case projects-Pars, Samand, Soren, and Dena-and its products before undertaking these projects shows that IKCO has developed knowledge of designing cars across the case projects. The knowledge that IKCO had before these case projects was restricted to production engineering knowledge, which only allowed the company to improve production efficiency without being able to make any changes in product design. This point was raised within the interviews. For example, one participant commented:

... we couldn't even touch the design ... the product that we were assembling had its antenna on the right side based on its original English style of car design and we couldn't even adjust it our style and transferring it to left side after 20 years of producing that.

However, by undertaking the case projects, IKCO started to change the design of its products and, over time, gradually increased the depth of changes (depth of innovativeness) which eventually resulted in changing the whole design of the product. Such progress in depth of innovativeness and developing "design knowledge"

First, IKCO gained knowledge of body design during its cooperation with Peugeot while developing Peugeot's Pars product. The scope of change within this project was limited to changing the body of the car. Since the technology base of Peugeot's products was higher than the technology base available in IKCO, it can be concluded that co-development of one of Peugeot's products gave IKCO the opportunity to learn about the general dimensions of the new technology related to IKCO"s task within the auto industry.

Second, within the Samand project, IKCO changed components within the subsystems of its products. During this stage, IKCO developed a national CNG-based engine called "EF motor" for the Samand product. As a result of this change, IKCO adopted the new "power train" system for motors (as a component) to use in its products. Accordingly, IKCO developed knowledge of designing components and matching them within a subsystem. Since during this project IKCO changed the components within a subsystem to components based on new technology, we can identify the application of the new technology in relation to each function.

Third, IKCO experienced changing subsystems. For instance, during their development of the Soren product, IKCO designed a new axel for the "drive train" subsystem along with adopting air bags and an ABS system within the "electric/electronic subsystem". Indeed, IKCO developed knowledge of changing different subsystems. Since during this project IKCO changed subsystems to new technologybased subsystems, it can be concluded that the application of new technology identified in the Samand project was connected to practices within functions resulting in the changed subsystems.

Finally, the fourth step involved more radical change in different subsystems, upgrading them in accordance with a higher level of technology. During the Dena project, IKCO had to match different subsystems (based on new technology) together, forming new architecture. The new architecture included a new platform for the company's products based on a new configuration of the product's subsystems. For example, within the Dena project, IKCO developed a new CNG-based platform which was a new-to-world platform based on the knowledge specifically developed at IKCO. In other words, IKCO changed the configuration of subsystems. Since during this project IKCO used a new technologybased configuration for its subsystems, it can be concluded that the technological knowledge which was combined with practices within functions (in the Soren project) was applied to organizational outcomes, resulting in the development of new product architecture.

Moreover, the knowledge creation steps indicate that IKCO, initially in the Pars project, learned to change parts, then in the Samand project IKCO learned how to reconfigure parts and develop new components (within subsystems). Furthermore, during the Soren project, IKCO learned about reconfiguring components and developing subsystems, whereas within the 
Dena project, it learned about reconfiguring subsystems and developing a new product architecture.

Indeed, IKCO has gradually developed the knowledge of interactions among different product elements and the capability to integrate them from the part level to the architectural level of the product architecture. Eventually, by reflecting such knowledge and capability developed within functions in the product architecture, new ways for interactions among functions leading to required product performance in the market is revealed.

Accordingly, we may expect that across the four product innovation projects, new knowledge and capability has been created at IKCO. The next section describes the findings of this study with regards to such knowledge and capability creation.

\section{Development of architectural knowledge at IKCO}

Before starting these four projects, IKCO held some engineering and production knowledge of auto making; however, they had no knowledge of new product development. As one informant described:

We produced Peykan [name of an old product of IKCO] for 40 years but nothing happened. We were just told "today, produce 50 cars, for tomorrow make it 60 cars and for the next day make it 100 cars". In terms of resources they calculated for this level of production we need to add some extra manpower and we had to buy some extra raw material. The content of meetings was also about such concerns. But when it comes to changing the product, some other types of resources are needed. You need to know more depth of the product and discuss different dimensions of it.

The knowledge which enables an automaker to innovate and develop new products is not a simple knowledge to learn, as one informant put it:

The design processes are very complex and developing a product throughout these complex processes needs solid experiences for putting these processes in the right order and making the new product out of them.

As another informant explained, this knowledge is gained through experience accumulation over time:

From different ways from copying processes to knowledge development processes, Toyota could absorb a great deal of knowledge which brought Toyota up to a level that even Americans prefer to buy from Toyota rather than American big players.
However, it doesn't mean that without having such experience, a less experienced firm cannot innovate in this industry, as this informant continued:

What today's competition needs is not just true and radical innovations; however, innovation speed is even more important. For example, Hyundai some time ago presented Santafe and then after a period of time it presented the next product to the market, but today it has changed its innovation policy to slight but frequent changes which enables Hyundai to cover a wider range of consumer tastes more efficiently.

In this type of competition, a firm does not need to have depth of knowledge which is more necessary for radical types of innovation; rather, for lower levels of innovation, firms need just to have the capacity to apply the knowledge of others. Firms will also have to integrate their knowledge with that of external firms in order to develop products. Hence, a prerequisite for outsourcing knowledge is having the ability to integrate external knowledge with internal knowledge which is called absorptive capacity (Cohen \& Levinthal, 1990). Absorptive capacity allows a firm to be more focused on their strategic assets by outsourcing some knowledge to external sources. Firms try to focus on strategic assets and leave the rest to be outsourced to other firms, as one informant mentioned: "We have two options for enjoying design knowledge, one is to take the action and learn it and the other option is to use the advanced knowledge that European companies have."

IKCO used its absorptive capacity to benchmark activities. In fact, they learned how to integrate the external ideas from best practices to the company's practices. Basically, an idea generated externally is sensed at the organizational and functional levels and is then disseminated at the component and system levels.

IKCO doesn't claim to have auto making knowledge but, as another informant described, they can use external knowledge and incorporate it into their current tasks and create new products having elements of new knowledge in them:

First we left the project management responsibility to them and then we cooperated with them and were trained at all levels from staff to managers. This is how we absorbed the knowledge. We combined the knowledge that we had with their knowledge toward creation of a car.

IKCO integrated external knowledge into its previous body of knowledge throughout the completion of the four new product development projects: Pars, Samand, Soren, and Dena. In addition, it can be argued that the nature of knowledge created at IKCO was "architectural knowledge"

ISSN: 07 I8-2724. (http://www.jotmi.org) 
(Henderson \& Clark, 1990), being the knowledge of product architecture, and refers to the knowledge of the true underlying structure of interdependencies among the components and subsystems within the product architecture.

\section{Development of architectural capability at IKCO}

In the case of the Iranian automotive industry, before the Pars project, IKCO was the only key player in the market, and the source of economic return was cost reduction because the production scale and market share were secure. IKCO had the situation of enjoying "Ricardian rents" as a result of a static environment. However, with the changing government policies toward opening the doors for car imports and the emergence of some carmakers inside the country, the situation was changed to a more competitive environment. Hence, the source of economic return switched to "Schumpeterian rents" in a more dynamic environment. One informant explained this:

Before Pars, we had been focused on localization of production of parts and self-sufficiency which made the cost lower. This was the profiting mechanism at that time. However, later, the situation turned to a more competitive environment ... the products within the markets became more diversified covering a wide range of consumers' tastes and we had to innovate and diversify our products.

In general, by increasing the level of competition in the marketplace, automakers' competitive advantage in terms of differentiation of their products compared to rivals' products doesn't last long. As one informant explained:

The life cycle for a platform has been shortened compared to what we had before. It is because of competition, environmental requirements, standards as well as technological changes. For example, we have worked with Euro-4 standards but now we have to work with Euro-5 standards. The tastes of the consumers also changes; for example, they ask for upgrading the dynamic characteristics of a car like changes in the handling system or flexibility in the car's wheel. Or, we have to design cars with more economic fuel consumption level which make us make cars lighter and apply new technologies. So, automakers have to change the platforms more frequently.

In summary, by increasing the degree of competition, the capabilities of firms (which are sources of competitive advantage) are imitated by competitors, and firms' competitive advantage erodes over time. The new source of advantage is rooted in meeting consumers' needs ahead of rivals.As explained by one informant: "Ten years ago an airbag was an option which an automaker could charge the customer for but now it is a basic option not a luxury option."
Hence, competition is based on continuous improvement of a product's position within the market and among rival products. Indeed, as one participant mentioned, competition in the automotive industry is based on having "innovation capabilities": "The competitive advantage within the automotive industry is just innovation. Everyone in the world who is innovative and creative is successful in today's market ... IKCO survives because of its R\&D."

Hence, firms need to be able to renew their capabilities and create new capabilities (Zollo \& Winter, 2002). In the automotive industry, firms need to develop "design capabilities" to be able to change their "operational capabilities" (Winter, 2003). In order for IKCO to develop design capability, it had to grasp the knowledge of designing. As another informant explained:

The foundation for managing quality and price is knowledge of designing. For example, Megan has been designed by Renault. This company has defined Logan which is a cheaper version of Megan for some markets like India, Iran, Brazil and ... they made this goal by using their design knowledge like in changing the tolerance of doors' fitting or changing the materials used for the dashboard or changing some curves in the design which make the production cost lower and manufacturing of it easier.

In fact, the knowledge which enables a firm to achieve continuous innovation and always have updated products in accordance with market needs is the competitive knowledge that any firm needs to be successful in the automotive industry. The knowledge needed in the automotive industry is less of a technological knowledge and more of a type of capability to integrate different knowledge bases.

Indeed, in the context of the auto industry, dynamic capability (Teece, Pisano, \& Shuen, 1997) has implications for developing design capability as innovation capability. More specifically, in the automotive industry this ability refers to "cascading capability" (in the words of the informants), which is the ability to reflect the market needs at different levels, including parts, components, subsystems, and the product architecture (configuration of subsystems). In fact, developing innovation capabilities within the case company can be investigated by considering data collected on the ability to integrate lower-level elements in order to create certain properties at a higher level (while designing a car).

In particular, in this regard IKCO had developed a Product Development Process (PDP) over the time and across the case projects. The PDP document was based on the formation of "cascading capability" at IKCO over the period of time during which IKCO completed the four case projects (Pars, Samand, Soren, and Dena). Indeed, developing this document refers to the development of "design

ISSN: 07 I8-2724. (http://www.jotmi.org) 
capability" across the case projects which enabled IKCO to be innovative (developing "innovation capability") and adapt the company's product with the dynamics of market requirements (developing "dynamic capability").

Indeed, organizational abilities of the case company have been identified at different levels.Abilities at the architectural level refer to the ability to design product architecture which fits market requirements. In fact, the nature of capability created can be argued to be "architectural competence" (Henderson and Cockburn, 1994), the ability to access new knowledge from outside the boundaries of the organization and the ability to integrate knowledge flexibly across disciplinary and therapeutic class boundaries within the organization.

Transformation of IKCO's capability base and emergence of modular product architecture

Along with creation of new knowledge and capability at the case company, IKCO"s previous capability transformed and evolved into a new form. Such capability evolution in this study was found to be in form of emergence of modular product architecture out of the existing product base of the company. Within the auto industry, along with capability development, firms tend to increase their level of outsourcing. One participant commented on the role of such an outsourcing trend as:

The most important issue impeding us from being innovative refers to our supply chain. If we want to be global we have to have a "global supply chain". Most of the automakers in the world just focus on a small scope within the value chain and the rest is done by supply chain. The role of the supply chain is not only procurement but a "global supply chain" is also responsible for designing. Indeed, a great part of the job is done by them. Today, we no longer see any OEM [Original Equipment Manufacturer here refers to automakers] to design a seat or steering wheel and the job is handled by suppliers. This makes carmakers flexible enough to be more innovative.

In this regard, across case projects, IKCO has followed this increasing trend in outsourcing its products' subsystems. Another participant pointed out:

We cannot deal with 5000 spare parts supplier and giving specifications for every individual part and exchanging engineering documents for each of them. But, we need 10 tier-one suppliers which give us a whole system. The tier-one would cascade to the lower-level spare parts suppliers; however, we as an OEM have the knowledge and capability to integrate the whole product, not them. We do the integration of the systems and styling and leave the designing at the " $A$ " surface level with them. In terms of production, we keep pressing and body shop (which mostly include assembling) inside and outsource the rest.
Based on participants' views, within the auto industry, when "modularity of product architecture" increases, some activities form a "bottleneck" for performance (Jacobides et al., 2006) and, hence, become strategic.

Furthermore, through emergence of such strategic activities, firms may focus on those activities in order to benefit most from the value embedded in such strategic activities. Such a focus on strategic activities enables firms to achieve "mass customization" (Sanchez, 1995), which is an ability to apply the same product base to different product markets. As a result of this trend towards mass customization, "commonality" among different products of a company increases. One participant raised this point as:

Before, three types of engines were put on Peugeot 405, and it was called "commonality". However, in today's meaning, commonality arises as using the same platform with slight difference for distant classifications of car such as a van and coupe.

In conclusion, it appears that automakers, through modularity of organizational architecture, approach the emergence of a "product platform". In this regard, Ulrich (1995) has defined product architecture as "the scheme by which the function of a product is allocated to physical components". In addition, Baldwin and Clark (2000) defined modularity as increasing interdependencies within subsystems while decreasing interdependencies among subsystems. On the other hand, by outsourcing subsystems, the interdependencies within subsystems are increased and function-specific tasks within functions are separated from firm-specific tasks and, therefore, "modularity in product architecture" is achieved.

\section{Discussion}

Findings of this study show that across the four product innovation projects, architectural knowledge and capability have been created at the IKCO company. In this regard, different product innovation projects included change at different levels of product architecture. This research revealed that along with changes at each level of product architecture (within each case project) "design knowledge" and "design capability" have been developed at the same level of product architecture, leading to capability development at that level. Furthermore, it was found that such capability transformation resulting from such knowledge and capability creation over the course of case projects included modularization of product architecture. Therefore, strategic capability development in this case can be interpreted as modularization of organizational capability architecture (Grant, 1996), enabling firms to develop more modular new products capable of meeting a wider range of market requirements and more easily customized. 
More specifically, and bringing all these findings together, it can be argued that along the step by step maturation of radical innovation across the four case projects, architectural knowledge and capability have been developed at the case company, resulting in the gradual emergence of a modular product and capability architecture across different levels of product architecture. Such findings basically add to extensive emphasis in the literature on the interrelationship of the concept of modularity with knowledge management and capability development (Baldwin \& Clark, 2003; Campagnolo \& Camuffo, 2010; D'Adderio \& Pollock, 2014; Ethiraj \& Levinthal, 2004; Fixson \& Park, 2008; Garud, Kumaraswamy, \& Langlois, 2009; Schilling, 2000; Ulrich, 1995). In particular, this argument extends the original suggestion of Sanchez and Mahoney (1996), who argued that creation of architectural knowledge and capability as a result of knowledge integration within product innovation would lead to modularization of organizational capabilities.

Accordingly, IKCO has dynamically managed product innovation projects to increasingly develop the depth of innovation from part level up to architectural level. By maturation of radical product innovation, IKCO has gradually developed the architectural knowledge of the information structure of its products' structure and the architectural capability to change its product structure. Such findings are aligned with Sanchez and Mahoney (1996), who argued that by developing architectural knowledge and capability, firms would achieve a complete "information structure" upon which they could increase "strategic flexibility", leading to the emergence of "modular capability architecture".

Consistent with this view, architectural knowledge and capability have been gradually created across the four product innovation projects. By developing design knowledge, IKCO was able to change components and subsystems, which is consistent with achieving "resource flexibility" (Sanchez, 1995). On the other hand, by developing design capability, IKCO was able to reconfigure existing components and subsystems for meeting market requirements, which matches achieving "coordination flexibility" (Sanchez, 1995). Since Sanchez (1995) argued that by developing "resource flexibility" and "coordination flexibility" firms develop strategic flexibility, it can be concluded that IKCO has actually developed strategic flexibility, which refers to the development of modular product architecture. Such analysis is consistent with the findings of this research, revealing the emergence of modular product architecture across the case projects.

However, step by step maturation of product innovation and integration of knowledge from part level up to architectural level of product innovation has led to "design knowledge" and "design capability" creation across the case projects, and the gradual creation of information structure at different levels of product architecture. In this regard, findings of this research extend the theory suggested by Sanchez and Mahoney (1996) to different levels of product architecture. More specifically, this study shows that development of information structure at lower levels of product architecture is the basis for knowledge integration at higher levels and undertaking deeper product innovation project.

Accordingly, the original argument put forward by Sanchez and Mahoney (1996) at architectural level of a product holds true for other levels of product architecture. Product innovation projects at part levels, which includes integrating parts, has made a base for IKCO to undertake the following product innovation project at component level-integrating parts in different forms to achieve new components for the product. Similarly, the product innovation project including integration of components has enabled the case company to create new subsystems in the following product innovation project by flexibly integrating components of the product. Equally, changes at subsystem level have enabled IKCO to eventually introduce a whole new product architecture and a radically new product. As a result, IKCO, in pursue of strategic capability development, has dynamically managed a sequence of product innovation and the associated knowledge processes, such that along with progressive increases in the depth of product innovation projects (toward radical product innovation), its capability architecture becomes modularized.

\section{Conclusion}

Organizational capability development has been emerged as a dominant theoretical framework for explaining firms' generation of and maintaining of competitive advantage. As a result, a debate has been raised on conceptualization of capability development to examine how strategic capability and competitive advantage build up over time. Scholars of the competence based view argued that capabilities are developed which fit with market requirements, and scholars with the opposing perspective of a capability based view argue that capabilities are path dependent and built upon the existing capabilities, not market requirements. This study found that these two separate views are partially true and complement each other. Indeed, investigating the transformation of organizational capability over the course of four product innovation projects revealed that, by maturation of product innovation projects towards radical innovation, existing organizational capability has evolved toward to a new organizational capability which matches market requirements.

Academically, such conceptualization which has been referred to as "strategic capability development",encompassing both 
content and process of capability development, and links the evolutionary view of strategic management to the positioning view. In this regard, findings of this research suggest that firms' existing capabilities continuously evolve towards market requirements as they adapt their existing products to the ever changing customer needs. Therefore, the transformation of past capabilities is not separate from what the market requires but they are guiding and complementing each other. Such integration of both views is accommodated by conceptualization of organizational capability development as modularization of organizational past capabilities, which enables firms to "mix and match" their existing products elements to meet new customer requirements.

Practically, findings of this research reveal the step by step nature of capability development in firms. In particular, this study highlights the importance of product innovation projects as the means of such capability development. Results show that such capability development is achieved over the course of four product innovation projects where radical innovation matures gradually from part level up to architectural level. Therefore, practitioner may learn from such findings to transform organizational capabilities through dynamically managing innovation at different levels of product architecture across a sequence of product innovation projects.

\section{About Authors}

Alireza Javanmardi Kashan is a researcher within the School of Management at the Queensland University of Technology. $\mathrm{He}$ has recently completed a $\mathrm{PhD}$ research program in strategy, innovation management and entrepreneurship, entitled:"Strategic Capability Development:A multi-level case study of knowledge integration within product innovation". $\mathrm{He}$ has extensive experience in both academic and industry contexts and also has served previously as a R\&D manager within a major manufacturing company in Iran.

Kavoos Mohannak is a Senior Lecturer in the School of Management at the Queensland University of Technology. Currently he teaches courses on entrepreneurship, technology and innovation management. His research program is based around developing and enhancing understandings of innovation systems; knowledge management and integration both at firm level and from a conceptual and cross-cultural perspectives; universityindustry linkages; technology transfer \& commercialisation and analysis of industry clusters. Much of his work in these areas has appeared in international journals and scholarly books. He also has conducted research on cultural aspects of knowledge management and has published an edited book on Knowledge Management in Developing Countries.

\section{References}

AMBROSINI, V., \& Bowman, C. (2009) What are dynamic capabilities and are they a useful construct in strategic management? International Journal of Management Reviews I I I ), 29-49. DOI: I0.I I I I/j. I 468-2370.2008.0025 I.x

BALDWIN, C.Y., \& Clark, K.B. (2003) Managing in an age of modularity. In: R. Garud,A. Kumaraswamy, \& R. Langlois (eds.) Managing in the Modular Age:Architectures, Networks, and Organizations (Pp. |49-17I). John Wiley \& Sons, Hoboken.

BARNEY,J. (199I) Firm resources and sustained competitive advantage. Journal of Management 17(I), 99-120. DOI: 10.1177/014920639101700108

BARNEY, J., Wright, M., \& Ketchen, D.J. (200I) The resource-based view of the firm: Ten years after 1991. Journal of Management 27(6), 625-64l. DOI: I0.1 I77/01492063010270060।

CAMPAGNOLO, D., \& Camuffo, A. (2010) The concept of modularity in management studies: A literature review. International Journal of Management Reviews 12(3), 259283. DOI: I0. I I I I/j. I 468-2370.2009.00260.x

CAVUSGIL, S.T., Calantone, R.J., \& Zhao, Y. (2003) Tacit knowledge transfer and firm innovation capability. Journal of Business \& Industrial Marketing 18(1), 6-2I. DOI: |0.1 |08/088586203104586|5

COHEN,W.M., \& Levinthal, D.A. (1990) Absorptive capacity: A new perspective on learning and innovation.Administrative Science Quarterly 35(I), I28-152. DOI: 10.1016/b978-07506-7223-8.50005-8

D'ADDERIO, L., \& Pollock, N. (20I4) Performing modularity: Competing rules, performative struggles and the effect of organizational theories on the organization. Organization Studies, I-3I. DOI: I0.1 I 177/ 0I708406 |4538962.

DANNEELS, E. (2002) The dynamics of product innovation and firm competences. Strategic Management Journal 23(I2), I095-II2I.DOI: 10.1002/smj.275

DOSI, G., Nelson, R.R., \& Winter, S.G. (eds) (2000) Introduction: The nature and dynamics of organizational capabilities. In:The Nature and Dynamics of Organizational Capabilities (pp. I-24). Oxford University Press, Oxford/ New York. DOI: 10.1093/0199248540.003.000 I

EISENHARDT, K. M. (1989) Building theories from case study research. Academy of Management Review 14(4), 532-550. DOI: |0.4|35/978|4|2986274.n I 
EISENHARDT, K.M., \& Martin, J.A. (2000) Dynamic capabilities: What are they? Strategic Management Journal 2I(I0-II), II05-II2I. DOI: 10.1002/1097-0266(2000 I0/II)2I:10/II\%3CII05::aidsmj I33\%3E3.0.co;2-e

EISENHARDT, K.M., \& Santos, F.M. (2002) Knowledge-based view: A new theory of strategy. Handbook of Strategy and Management I, I39-I64. DOI: 10.4I35/978|8486083 I3.n7

ETHIRAJ, S.K., \& Levinthal, D. (2004) Modularity and innovation in complex systems. Management Science 50(2), I59-I73. DOI: 10.2139/ssrn.459920

FIXSON, S.K., \& Park, J.-K. (2008) The power of integrality: Linkages between product architecture, innovation, and industry structure. Research Policy 37(8), I296-1316. DOI: I0.1016/j.respol.2008.04.026

GARUD, R., Kumaraswamy, A., \& Langlois, R. (2009) Managing in the Modular Age:Architectures, Networks, and Organizations. John Wiley \& Sons, Hoboken.

GRANT, R.M. (1996) Prospering in dynamically-competitive environments: Organizational capability as knowledge integration. Organization Science 7(4), 375-387. DOI: 10.1016/b978-0-7506-7088-3.500। I-5

HELFAT, C.E., \& Peteraf, M.A. (2003) The dynamic resourcebased view: Capability lifecycles. Strategic Management Journal 24(I0), 997-1010. DOI: 10.2139/ssrn.386620

HENDERSON, R., \& Clark, K.B. (1990) Architectural innovation: The reconfiguration of existing product technologies and the failure of existing firms. Administrative Science Quarterly 35(I), 9-30. DOI: I0.2307/2393549

HENDERSON, R., \& Cockburn, I. (1994) Measuring competence? Exploring firm effects in pharmaceutical research. Strategic Management Journal I5 (Winter Special Issue), 63-84. DOI: I0.1016/0024-630 I (95)94304-h

HOOPES, D.G., Madsen, T.L., \& Walker, G. (2003) Guest editors' introduction to the special issue: Why is there a resource-based view? Toward a theory of competitive heterogeneity. Strategic Management Journal 24(10), 889902. DOI: $10.1002 / \mathrm{smj} .356$

JACOBIDES, M.G.,Thorbjorn, K., \& Mie,A. (2006) Benefitting from innovation:Value creation, value appropriation and the role of industry architecture. Research Policy 35(8), 1200 |221. DOI: 10.2139/ssrn. 1309509
JOHNSON, G., Melin, L., \& Whittington, R. (2003) Guest editors' introduction. Journal of Management Studies 40(I), 3-22. DOI: I0. I I I / |467-6486.t0 I-2-00002

KASHAN, A.J., \& Mohannak, K. (20I4) A conceptual analysis of strategic capability development within product innovation projects. Critical Studies in Innovation. Prometheus. DOI: |0.1080/08|09028.20|4.9579| |

KIM, L. (1980) Organizational innovation and structure. Journal of Business Research 8(2), 225-245. DOI: 10.1016/0I48-2963(80)90012-0

$\mathrm{KOOHI}, \mathrm{I}$. (2006) Iran car industry policies. Journal of Applied Sciences 6(2), 4I6-4I8. DOI: I0.3923/jas.2006.4I6.4I8

LEE, K. (2005) Making a technological catch-up: Barriers and opportunities. Asian Journal of Technology Innovation 13(2), 97-|3|. DOI: I0. I080/|976|597.2005.96686/0

LEE,T.W. (1999) Using Qualitative Methods in Organizational Research. Sage Publications, Thousand Oaks. DOI: 10.1 108/ ccij-06-2013-0039

LEE, T.W., Mitchell, T.R., \& Sablynski, C.J. (1999) Qualitative research in organizational and vocational psychology, 19791999. Journal of Vocational Behavior 55(2), I6I-I87. DOI: 10.1006/jvbe.1999.1707

LICHTENTHALER, U., \& Ernst, H. (2007) External technology commercialization in large firms: Results of a quantitative benchmarking study. R\&D Management 37(5), 383-397. DOI: I0.I I I I/j. I467-93 I0.2007.00487.x

LICHTENTHALER, U., \& Lichtenthaler, E. (2009) A capabilitybased framework for open innovation: Complementing absorptive capacity. Journal of Management Studies 46(8), |3|5-|338. DOI: | 0.1 | | |/j. |467-6486.2009.00854.x

LIU, P.-L., Chen,W.-C., \& Tsai, C.-H. (2005) An empirical study on the correlation between the knowledge management method and new product development strategy on product performance in Taiwan's industries. Technovation 25(6), 637644. DOI: 10.1016/j.technovation.2003.1 I.00 I

LUPTON, N.C., \& Beamish, P.W. (2014) The mutual construction of knowledge transfer and shared context in capability development within the networked MNC. Knowledge Management Research \& Practice forthcoming. DOI: 10.1057/kmrp.20I4.25 
MILLER, C.C., Cardinal, L.B., \& Glick, W.H. (1997) Retrospective reports in organizational research: A reexamination of recent evidence. Academy of Management Journal 40(I), I89-204. DOI: I0.2307/257026

PETERAF, M.A. (1993) The cornerstones of competitive advantage: A resource-based view. Strategic Management Journal I4(3), I79-19I. DOI: I0.1002/smj.4250I40303

PETTIGREW, A.M. (1990) Longitudinal field research on change: Theory and practice. Organization Science I(3), 267-292. DOI: I0.1287/orsc. I.3.267

RUSH, H., Bessant, J., \& Hobday, M. (2007) Assessing the technological capabilities of firms: Developing a policy tool. R\&D Management 37(3), 22I-236. DOI: 10.1 III/j.I467$93|0.2007 .0047| . x$

SANCHEZ, R. (1995) Strategic flexibility in product competition. Strategic Management Journal I6(SI), 135-159. DOI: I0.1002/smj.425016092I

SANCHEZ, R., \& Heene, A. (2004) The New Strategic Management: Organization, Competition and Competence. Wiley. DOI: I0.1016/s0263-2373(97)00010-8

SANCHEZ, R., \& Mahoney, J.T. (1996) Modularity, flexibility, and knowledge management in product and organization design. Strategic Management Journal I7(S2), 63-76. DOI: I0.1002/smj.4250I7II 07

SCHILLING, M.A. (2000) Toward a general modular systems theory and its application to interfirm product modularity. Academy of Management Review 25(2), 312-334. DOI: 10.5465/amr.2000.3312918

SCHUMPETER, J.A. (1942) Capitalism, Socialism and Democracy. New York, Harper and Row. DOI: 10.4324/9780203857090

SLATER, S.F., Mohr, J.J., \& Sengupta, S. (2014) Radical product innovation capability: Literature review, synthesis, and illustrative research propositions. Journal of Product Innovation Management 3I(3), 552-566. DOI: I0.1III/ jpim. 12113

SMINIA, H. (2009) Process research in strategy formation: Theory, methodology and relevance. International Journal of Management Reviews II(I), 97-125. DOI: 10.1III/j.I4682370.2008.00253.x
SUBRAMANIAM,M.,\&Venkatraman, N.(200I) Determinants of transnational new product development capability:Testing the influence of transferring and deploying tacit overseas knowledge. Strategic Management Journal 22(4), 359-378. DOI:I0.1002/smj. I63.abs

TEECE, D.J., Pisano, G. and Shuen, A. (1997) Dynamic capabilities and strategic management. Strategic Management Journal I8(7), 509-533. DOI: 10.1016/b978-0-7506-70883.50009-7

TIPPMANN, E., Mangematin, V., \& Scott, P. S. (2013) The two faces of knowledge search: New solutions and capability development. Organization Studies 34(I2), I869-1901. DOI: I0.1 I77/0I708406/3485846

ULRICH, K. (1995) The role of product architecture in the manufacturing firm. Research Policy 24(3), 419-440. DOI: 10.1016/0048-7333(94)00775-3

VERONA, G., \& Ravasi, D. (2003) Unbundling dynamic capabilities: An exploratory study of continuous product innovation. Industrial and Corporate Change 12(3), 577606. DOI: 10.1093/icc//2.3.577

WINTER, S.G. (2003) Understanding dynamic capabilities. Strategic Management Journal 34, 991-995. DOI: 10.1002/ smj.318

ZOLLO, M., \& Winter, S. G. (2002) Deliberate learning and the evolution of dynamic capabilities. Organization Science I3(3), 339-35I. DOI: I0.1287/orsc. 13.3.339.2780 